\title{
OPINION
}

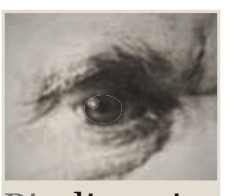

\section{Costing the Earth}

\section{The value of biodiversity must be accounted for, says Pavan Sukhdev. It is time for \\ Biodiversity governments to invest to secure the flow of nature's 'public goods'.}

$\sim$ lean air, fresh water, the flood protection provided by wetlands, the carbonstorage capacity of forests: these are examples of natural systems and processes that we largely take for granted. We consider them 'public goods': they are available to everyone; there is enough to go round; and one person's enjoyment of them does not impede another's. They are not traded in markets, not priced and they are mostly available for free.

This attitude, held the world over by everyone from consumers to policy-makers, demonstrates a lack of understanding about the finiteness and fragility of ecosystem services. Their contribution to national gross domestic product (GDP) and to human well-being is barely recognized. The inevitable outcome is a situation described by ecologist Garrett Hardin more than 40 years ago as the 'tragedy of the commons', in which individuals who consume a shared resource according to their own self-interest are bound to destroy it (G. Hardin Science 162, 1243-1248; 1968).

The tragedy of the commons is now greater than ever. Many natural resources are under increasing pressure from over-exploitation and changes of land use and yet still are available free of cost. The main problem is that ecosystems and biodiversity provide both private and public goods. For example, a logging company might pay for the right to harvest trees, but no one provides compensation for the loss of carbon storage that results from felling them.

Furthermore, many natural resources are 'open access' and not covered by property rights or effective national laws or international treaties, which leads to their constant depletion. For example, open access and a perverse system of subsidies have left two-thirds of fish stocks across the globe over-exploited, and have damaged coastal ecosystems. This threatens both the fisheries industry, which generates income of US $\$ 80$ billion- $\$ 100$ billion annually, and the livelihoods of 27 million people who depend on fisheries, most of whom are poor, small-scale fishermen. Additionally, more than a billion people, mainly in developing countries, rely on fish as their main or sole source of animal protein.

There is a pattern here: poor people are almost always hit hardest by the misuse of environmental resources as they depend on them most heavily. A recent attempt by the Green Indian States Trust (GIST), a non-governmental organization that promotes sustainable development, to develop a 'GDP of the poor' in India is a good illustration. The trust showed that although the value of forest services such as fresh water, soil nutrients and non-timber forest products was only around $7 \%$ of national GDP, it amounted to some $57 \%$ of the income of India's rural poor people (see graph).

There are many calls for changes to the current economic paradigm to solve this problem of declining public goods. One is through TEEB (the Economics of Ecosystems and Biodiversity), a major global study to draw attention to the tangible benefits of biodiversity, and to highlight the growing costs of biodiversity loss and ecosystem degradation (www.teebweb.org).

ECOSYSTEMS AND POVERTY IN INDIA

Classic gross domestic product (GDP)

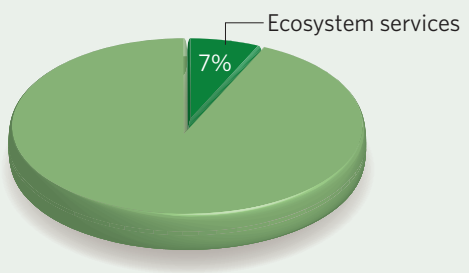

'GDP of the poor'

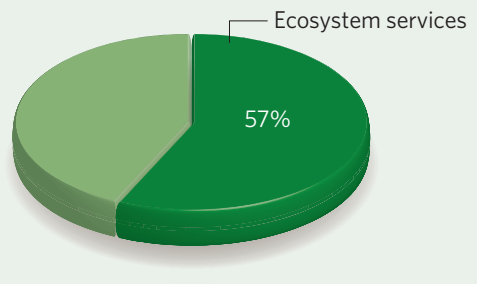

There are several realistic approaches on the table, including those developed by this year's joint-winner of the Nobel prize in economics, Elinor Ostrom. In her studies of resources such as forests, lakes, fish stocks and pastures, Ostrom found many cases in which communities have developed sophisticated mechanisms for the successful management of common property (E. Ostrom et al. Science 284, 278-282; 1999).

Indeed, there is a wealth of initiatives around the world that work. In Costa Rica, for example, payments for environmental services have become virtually a countrywide strategy for forest and biodiversity conservation. They are funded largely from transportation taxes, directly benefit farmers who resolve to retain forest patches on their lands and indirectly benefit many others who enjoy the continuing 'public' benefits from these forests. Companies are also increasingly seeing value in biodiversity preservation and recognizing the interconnectivity with long-term business durability. Insurance firms and shipping companies have financed the reforestation of the Panama Canal region to restore freshwater flow to its locks and prevent the rise of shipping premiums caused by the risk of canal closures.

It is now up to governments to provide fiscal or other incentives to encourage the participation of stakeholders as responsible stewards rather than short-term optimizers. This can be done by reforming the way property and access rights are assigned, and through better targeting of taxes and subsidies. Globally there are many unused opportunities.

One game-changing mechanism being discussed at the UN climate conference in Copenhagen later this year is REDD+, a proposed scheme to reward reductions in deforestation and degradation, as well as rewarding more afforestation or reforestation, and effective conservation. This links the maintenance of ecosystems with the climate challenge by setting up a global scheme to reduce emissions from forest losses (which are close to a fifth of all emissions) and to encourage more and better carbon capture through forestry. Many countries are already developing capacity to implement REDD+. The upside of such preparation is significant - it could set up a framework that might be used to reward other 'public goods' such as freshwater capture and storage, species conservation and community livelihoods.

There are signs that countries are willing to put new economic models in place to stop the misuse of their environmental resources and to limit degradation. Although many uncertainties remain, good ideas for change are close at hand. We just have to lean forwards and pick them up.

Pavan Sukhdev is study leader of the Economics of Ecosystems and Biodiversity (TEEB) project, United Nations Campus, Hermann-EhlersStrasse 10, 53113 Bonn, Germany.

e-mail: teeb@unep-teeb.org

See Editorial, page 251, News Feature, page 270 , and biodiversity special at www.nature.com/ darwin. To hear an interview with the author see go.nature.com/oLMXVt 